\title{
Um oblívio de Kant ${ }^{1}$
}

DAniÈLE Cohn - Universidade de Paris 1 - Panthéon-Sorbonne

Tradução de Fabio Stieltjes Yasoshima

Em seu Prefácio a Idee und Gestalt ${ }^{2}$, uma compilação de estudos sobre Goethe, Schiller, Hölderlin e Kleist, publicada em 1921, Cassirer justifica as análises "literárias" que constituem seu objeto mediante certo nexo da ideia à forma:

Nestes estudos, trata-se de ressaltar as conexões e mediações que fazem a passagem do mundo das ideias filosóficas ao mundo da forma poética. Em tais mediações e passagens, as ideias revelam seu pleno teor: torna-se evidente que os pensamentos verdadeiramente criati-

\footnotetext{
${ }^{1} \mathrm{O}$ presente texto foi publicado com o mesmo título - "Un oubli de Kant" - no livro da Profa. Danièle Cohn intitulado L'Artiste, le vrai et le juste: sur l'esthétique des Lumières, Paris, Éditions Rue d'Ulm/Presses de l'École normale supérieure - musée du quai Branly, 2014, p. 35-54. A presente publicação foi autorizada pela autora.

2 Idee und Gestalt é o título de uma obra de Cassirer datada de 1921, cuja tradução francesa deveria ser publicada pelas Éditions du Cerf em 2015; edição alemã, Darmstadt, Wissenschaftliche Buchgesellschaft, 1975.
} 
vos, ao lado de seu conteúdo puramente abstrato, compreensível conceitualmente, contêm uma vida do espírito concreto que lhes é própria, uma força formativa e um poder de dar forma (Cassirer, 1975, Prefácio).

Em 1922, Benjamin, em seu ensaio As afinidades eletivas de Goethe, disso fará eco: "A crítica busca irmãos e irmãs da obra de arte. E todas as obras de arte autênticas possuem seus irmãos e irmãs no domínio da filosofia. São precisamente as figuras nas quais se manifesta o ideal de seu problema [...]" (Benjamin, 2000, p. 350).

As Luzes atribuíram duas virtudes às fábulas. Seu conhecimento é necessário, como explica o verbete "Mitologia", assinado por Jaucourt na Enciclopédia, pois "a fábula é o patrimônio das artes; é uma fonte inesgotável de ideias engenhosas, imagens aprazíveis, temas interessantes, alegorias e emblemas cujo uso mais ou menos feliz depende do gosto e do gênio" (Encyclopédie, X, p. 924). Espécie de reservatório de figuras, "até certo ponto, não é possível ignorá-la [a fábula] sem enrubescer desta falta de instrução" (Encyclopédie, VI, p. 344). A segunda virtude da fábula diz respeito à sua função em matéria de educação estética, isto é, sensível. Os diferentes ensaios e tratados de Lessing, suas próprias fábulas - pois ele as escreve - são testemunha disto. "Quando reduzimos uma proposição moral geral a um caso particular e conferimos realidade a este caso e, a partir disto, inventamos uma história, na qual reconhecemos intuitivamente a proposição geral, esta ficção se chama fábula" (Lessing, 2008, p. 59). Os pensadores das Luzes fazem uma reutilização das fábulas fabulosas da mitologia e lhes acrescentam variantes (ver Narciso, Ifigênia, Laocoonte) ou inventam, a exemplo de 
Lessing, fábulas novas. Rousseau, como bom platônico, em seu Emilio faz a conhecida crítica feroz das Fábulas de La Fontaine: contos pseudopueris e imorais (Rousseau, 1969, p. 353 et seq.). Mas seu preceptor constrói, segundo um critério de justeza ortopédica, fábulas que instruem sensivelmente por uma fábrica da experiência - pensemos, por exemplo, na cenografia do campo de favas e na cólera do jardineiro (Ibid., p. 331 et seq.). Tratase da exemplaridade do exemplo, do estatuto do caso singular, sensível; e do acesso ao geral que o caso singular bem escolhido possibilita. Lessing designa as fábulas deste modo: "Podemos dar este nome às fábulas: os exemplos da doutrina dos costumes" (Lessing, 2008, p. 55-56).

Kant não é conhecido como um filósofo que conta histórias, seja qual for o sentido que se atribui a esta expressão. No sentido da linguagem corriqueira, isto tornaria impossível toda confiança. Ora, para Kant, como veremos, a confiança é uma condição de possibilidade da intersubjetividade. Além disso, se Kant - eis o outro sentido da expressão "contar histórias" - só atribui muito raramente figuras às ideias, para emprestar esta fórmula de Cassirer, sua teoria do exemplo cruza as reflexões de seu tempo sobre a fábula. "A palavra alemã" Beispiel, que empregamos ordinariamente como sinônimo de Exempel, não possui o mesmo sentido. Tomar um Exempel e indicar um Beispiel para a compreensão de uma expressão são duas ideias bastante diferentes. O Exempel é um caso particular de uma regra prática, enquanto esta regra representa uma ação como praticável ou impraticável. Um Beispiel, pelo contrário, é apenas o particular (concretum) representado como conteúdo no geral concebido pelo espírito (abstactum), e a exibição puramente teórica de certo conceito" (Kant, 1985a, p. 157 et seq.). Cf. tb. a aná- 
lise feita por Fernando Gil em Exemple et pierre de touche chez Kant (Gil, 1991, p. 3-36) e em La bonne description (Idem, 1998, p. 129 et seq.). Ele distingue dois exemplos ao jogar com dois termos em uso no alemão. Se o Exempel ilustra uma regra geral da qual ele representa um caso particular e, por conseguinte, resulta de uma exemplificação, o Beispiel alcança a exemplaridade. O próprio Kant não é sempre totalmente rigoroso no emprego da distinção que ele estabeleceu. Pouco importa quanto à ocorrência; o que conta, a nosso ver, é a tensão fecunda assim instaurada entre exemplificação e exemplaridade. Esta efetua uma articulação entre singular e universal, particular e geral; e conduz a uma interrogação decisiva para a constituição de uma teoria da justeza: qual é o estatuto moral e cognitivo do exemplo - e da fábula - e que alcance prático ofereceria a constituição de tipos como aqueles promovidos pelas fábulas ou pelos exemplos? Há nisto matéria para uma típica propriamente estética, que, segura dos conhecimentos da "Típica da razão prática", na última parte da Crítica da Razão Prática, seria operatória para o pensamento sensível do sensível, que pretende ser a estética, e lhe daria uma força heurística nas suas reflexões sobre a atividade artística e as obras? Para Kant, em termos de moralidade pura, o exemplo não funda nenhuma "máxima da virtude"3, mas conserva, aos olhos do filósofo, uma "força" eficaz, muito próxima daquela que a retórica atribuía à illustratio e que a "Metodologia da razão pura prática" expõe. E esta luminosidade do exemplo desempenha um papel em nossa formação, na cultura; ela aguça nosso juízo ao mobilizar nossa atenção para uma série de ficções

3 "O bom exemplo - Exempel - não deve servir de modelo, mas somente de prova de que aquilo que é conforme ao dever é praticável" (Kant, 1985a, p. 158). 
que são outras tantas ações imaginárias. Isto também ocorre no exemplo de nossa relação com o universal, quando ele não pode se pautar pelo regime da "determinação", aquele da "aplicação" de nossos conceitos, pelo esquematismo, ao sensível; esta Anwendung que Kant trouxe à baila na Crítica da Razão Pura "O esquematismo é mais a representação de um método para representar um conjunto (por exemplo, "mil", conforme a determinado conceito, do que esta mesma imagem, que, em último caso, para mim seria difícil percorrer com os olhos e comparar ao conceito. Ora, é a esta representação de um procedimento geral da imaginação para dar a um conceito sua imagem que eu chamo de esquema para este conceito" (Kant, 1986, p. 151153). As Luzes construíram um vínculo entre educação estética e educação moral, fazendo do estágio estético uma etapa do desenvolvimento do espírito. A fábula, o teatro, o romance são chamados para ajudar a acelerar a marcha progressiva na direção de uma humanidade ideal. As artes, nesta óptica, funcionariam como "manifestações sensíveis" (Versinnlichungen) da ideia moral? As artes não são o "belo, [que] é símbolo do bem moral" no $§ 59$ da Crítica do Juízo. A arte não possui nada de uma metáfora, de uma tradução, de uma transposição. Ela não ilustra de diversas maneiras o bem moral: ela produz. E suas produções encontram-se em uma pressão constitutiva: há uma obrigação "moral" da arte que é a de não enganar e que nada tem a ver com o ilusionismo e o trompe-l'œil, mas que visa a sua verdade, sua justeza enquanto arte. A "moralidade" da arte resulta precisamente desta justeza que as obras apresentam nelas mesmas, de maneira interna, estrutural.

A concepção kantiana do exemplo se inscreve em um contexto e contra este mesmo contexto que é o da exaltação da emoção 
moral - ela recusa a função educadora desta sensibilidade intensa. Muito conhecida entre seus contemporâneos, a ideia de que o espetáculo tocante de uma conduta virtuosa produz, pela exacerbação da alma sensível, a imitação da virtude, é um erro aos olhos do filósofo: ela encoraja à Schwärmerei, este entusiasmo duvidoso que suscita nossa participação na representação do sofrimento dos outros e nossa satisfação em nos apiedarmos. O exemplo moral kantiano é uma manifestação sensível diferente. Ele palia a inaptidão do entendimento para conhecer as Ideias da razão com uma "alegorização" que o conceito - que é sua origem e seu modo de produção e, ao mesmo tempo, seu fim - decifraria com toda a facilidade hermenêutica. $\mathrm{O}$ fato de que Kant fale notavelmente a seu respeito tende a indicar uma dimensão de beleza própria à moralidade que resulta menos da elevação da alma que dela deriva do que da luminosidade própria à lei moral, que nossa intuição capta nos relatos que podem ser feitos em honra da nossa faculdade de julgar. Filosoficamente, o problema poderia ser enunciado nestes termos: no momento mesmo em que, por meio da crítica, Kant fixa os limites que estabelecem o regime das faculdades consideradas separadamente e, em seu funcionamento, uma em relação à outra, a eficácia de uma apropriação intelectual pela intuição ressurge na brecha que constitui a incomensurabilidade do poder do entendimento e do poder da razão. É por isso que o gênio e o poder de julgar, tais como a terceira Crítica os estabelece, são pontes lançadas sobre abismos criados pelas duas primeiras Críticas.

Uma obra de arte é percebida pelos sentidos, o entendimento pode descrevê-la em suas partes; mas a ideia de totalidade que lhe confere sua consistência não se deixa deduzir nem induzir do exame de suas partes. A unidade interior que lhe permite 
ser viva só pode ser apreendida pela intuição, quer se trate do criador, quer do espectador. A lebendige Darstellung, a animação da apresentação é o que faz a eficácia da obra de arte e o signo de que ela é um produto do gênio e não da regra da escola (Crítica do Juízo, § 47). O sentimento de justeza que a obra de arte nos concede e a convicção de que não nos enganamos na reatribuição à obra de sua justeza própria por nosso sentimento são ligados a isto: a obra não exemplifica - ou, pelo menos, essa não é sua intenção primeira nem o efeito que ela produz -, ela é exemplar. A declinação dos acordos entre as diferentes faculdades em um livre jogo regrado pela imaginação, por ocasião do julgamento estético, constitui um exercício da nossa liberdade da qual a obra do gênio é o produto e a ostensão. O lugar natural da aplicação do esquematismo é, por conseguinte, a razão teórica, pois ela mesma se constitui pela articulação entre duas séries de dados - os conceitos e as "intuições sensíveis". A dificuldade nem por isso é resolvida quando se trata do belo - dele não há conceito - e quando se trata da moral - dela não há intuição sensível.

É por isso que a típica é a solução do problema da razão prática e seria - esta é a nossa proposição - a solução de uma razão estética. Ela consistirá necessariamente em relacionar o conceito moral a outro conceito. Mas para que tal relação continue sendo um analogon do esquematismo, este segundo conceito deve ter certa relação com a experiência, conservando a universalidade do conceito moral. Portanto, ele é pensado como a universalidade das leis naturais consideradas enquanto tais, independentemente de seus conteúdos: "Não se trata, aqui, do esquema de um caso que ocorre segundo leis, mas do esquema (se é que este termo pode ser conveniente aqui) de uma lei" (Kant, 1985b, 
p. 690 et seq.). Em moral, o tipo só é apreensível, pensável, mediante exemplos; o exemplo moral sendo precisamente uma ilustração intelectual - trata-se da exemplaridade do exemplo e não imaginativa (tampouco puramente empírica: no exemplo, o empírico é visto através do universal) de um princípio que se apresenta in concreto. Nos casos empíricos, o exemplo permite pôr em ação a aplicação da lei de uma razão pura prática.

A Crítica do Juízo se ocupa da exemplificação quando se trata das diferentes belas-artes; ela examina a exemplaridade nos parágrafos que consagra ao gênio. O gênio é definido como uma originalidade, pois "ele é um talento que consiste em produzir aquilo a que não saberíamos dar nenhuma regra determinada", mas cujos "produtos devem ao mesmo tempo ser modelos, isto é, exemplares [...]" (Kant, 1965, p. 205). Assim, as obras seriam fábulas, ao menos aquelas dos artistas de gênio no sentido em que Kant o entende e que Schiller retrama a seu modo. Com efeito, pretendendo definir o gênio goethiano, Schiller, em uma carta a Goethe datada de 23 de agosto de 1794, demonstra sua leitura arguta das Críticas kantianas, a riqueza filosófica de sua correspondência e o vínculo que une - como o sublinham, nós vimos, Cassirer e Benjamin, nos anos 1920 - literatura e filosofia, sistemas e escritos de artistas. Ele se dirige assim àquele que, a seu ver, é um gênio completo - seu amigo Goethe:

O curso lógico que o espírito é pressionado a tomar, quando reflete abstratamente, não é nem um pouco compatível com a atividade estética, única criadora de formas. Donde mais uma tarefa para o senhor: pois, após ter passado da intuição à abstração, teve de passar, em seguida, por um movimento inverso: traduzir 
novamente os conceitos em intuições e transformar os pensamentos em sentimentos; já que, sozinhos, os sentimentos e as intuições fornecem sua matéria à produção do gênio (Goethe \& Schiller, 1994, p. 45).

Enquanto obra de arte, a fábula seria um exemplo "estético"; logo, uma ilustração imaginativa que apresentaria o tipo em uma singularidade individuada - cada obra -, sem que fossem interditadas a variação sobre o tema e a série das variantes. O que se passa quando um filósofo esboça uma pequena fábula no coração de sua reflexão sobre o belo, à margem dos parágrafos que ele consagra à arte e às belas-artes? Ele age como fabulista? Este fabulista do qual Lessing assim determina a tarefa: "O fabulista pretende nos convencer com vivacidade de alguma verdade moral singular"? (Lessing, 2008, p. 51)

\section{O rouxinol, o conto e o filósofo}

Publicado em 1843 e intitulado O Rouxinol, o conto de Andersen nos transporta de imediato a um maravilhoso excessivo, "rebuscado". Ao redor do castelo de porcelana fina do imperador da China, há um jardim - pedaço de natureza disciplinada, "pedagogizada" pelo jardineiro que, por meio de sua arte, a aperfeiçoa infinitamente. Este jardim estende-se tão longe que o próprio jardineiro não conhece o seu limite. Para além do jardim, uma floresta, com grandes árvores e lagos profundos, declina até o mar. Lá, a natureza recobra seus direitos. "Nos galhos das árvores vivia um rouxinol que cantava tão divinamente que até mesmo o pobre pescador, que tinha tanto com que se ocupar, permanecia imóvel e escutava...". O canto do rouxinol é 
tão belo que não se pode deixar de escutá-lo. Sublimidade da inocência - Schiller - que se dirige às almas não pervertidas; repouso e plenitude que são o tempo da pausa do suspense em uma vida acorrentada ao esforço, ao labor, à preocupação. Espécie de canto benfazejo das sereias, o canto do pássaro impõe a admiração, constrange à escuta; mas para suscitar o poético. A bela natureza inspira a arte: o canto do rouxinol convida a fantasia a seguir livre curso. Todos aqueles que tinham a sorte de escutá-lo, "colocavam o rouxinol acima de tudo". Como disse Goethe, ao comparar a Ottilie de suas Afinidades Eletivas ao pássaro cantor: "O rouxinol supera a sua classe". Ele não é um animal como os outros: ele é superior. O rumor alcança a corte do imperador, que exige escutar o rouxinol. O rouxinol se apresenta de bom grado à convocação, mesmo se "é na vegetação que o canto produz seu melhor efeito", mesmo se a sua "plumagem cinza parece demasiado comum" aos grandes dignitários. Pois, no palácio, tudo brilha e tudo rutila até se tornar insuportável. O excesso de preciosidade suprime a possibilidade de uma intersubjetividade, de um sensus communis, afirma Kant. "O rouxinol cantava tão deliciosamente que o imperador ficou com os olhos marejados, as lágrimas rolavam-lhe pelas faces, então o pássaro se superou." Sinceridade da voz que jamais engana e fala diretamente ao coração, diz Rousseau. Dom das lágrimas e estatuto da piedade.

Conhecemos a continuação. O pássaro é reduzido a uma servidão dourada até que, nesta fábula manifestamente rousseauísta, sobrevém um cintilante pássaro artificial de ouro e prata. O amor-próprio logo recobra seus direitos em um mundo que o canto do rouxinol jamais convenceu - aquele de uma corte invejosa do sucesso obtido, porém não desejado, pelo pequeno ani- 
mal. Voluntarismo do artifício, gratuidade da natureza. A corte reclama um dueto. Duo impossível: "O verdadeiro rouxinol cantava à sua maneira e o pássaro artificial seguia o movimento dos cilindros." O acordo não se produz. A mecânica da caixa de música em forma de pássaro repete sem parar um canto compassado que imita uma das melodias do rouxinol. "Ele obtinha tanto sucesso quanto o verdadeiro; e certamente era muito mais bonito de se ver: brilhava como um bracelete e um broche." O sucesso nada tem a ver com as lágrimas. O sucesso é social. As lágrimas são uma pura expressão da emoção interior. Jamais o pássaro artificial estará em condições de fazer chorar quem quer que seja. Mas o ouvido sem a vista não conseguiria satisfazer a sociedade pervertida: o atrativo é demasiado fraco. A corte sonha com adereço, arrebique, excitação. Ela quer ver, isto é, muito trivialmente, ter a vista saturada. E deixa escapar o que a verdadeira arte torna visível por si. O verdadeiro rouxinol se eclipsa, aproveitando a fascinação pelo pássaro artificial. A sociedade se regozija de ter conservado o melhor; pois, como diz o mestre de música: "Vede, senhores e nobres damas e, sobretudo, meu senhor, o Imperador: do verdadeiro rouxinol, jamais podemos prever o que virá. Quanto ao pássaro artificial, já está tudo determinado! Será assim e não de outra maneira! Podemos explicá-lo. Podemos desmontá-lo e mostrar o que a inteligência humana concebeu; ver como se apresentam os cilindros, como eles funcionam e como eles se ligam."

Duas estéticas afrontam-se, inconciliáveis. O saber mecânico e hábil, de um lado; a arte inexplicável em sua beleza, na lembrança de sua beleza. A beleza se torna uma lembrança, ela se associa a uma Sehnsucht. Contra a explicação desmanteladora, a descrição morfológica, afirma Goethe. Só há estética descri- 
tiva, diz Wittgenstein. Uma estética da criação viva se opõe àquela da proeza da repetição automática.

Conhecemos também o final do conto. Com o tempo, o desgaste das engrenagens reduz as performances do pássaro artificial. A morte se instala no coração do imperador. Ela o importuna. As boas e as más ações voltam-lhe à memória impiedosamente. Salmodia do remorso, da angústia. O imperador pede ajuda, o pássaro artificial se cala. Outra música surge então: "Era o pequeno rouxinol, o rouxinol vivo, pousado sobre o galho lá fora. Ele ouvira falar da desgraça de seu imperador, por isso viera cantar-lhe consolação e esperança." A música pode vencer a morte. Ela leva a esperança onde reina o desespero. O essencial é que a esperança existe, como na última estrofe das Urworte, ou nesta frase inscrita no coração das Afinidades Eletivas que tanto agradava Walter Benjamin: cesura da obra, dizia ele, "a esperança passou sobre suas cabeças como uma estrela que cai do céu." Responde-lhe outra frase que abre o final de seu ensaio sobre o romance de Goethe: "Para os desesperados apenas nos foi dada a esperança." Até a morte precisa de canto; e de mais canto. E "o rouxinol cantou-lhe o calmo cemitério onde crescem as rosas brancas, onde recende o sabugueiro e onde a erva verde é regada com lágrimas dos vivos. Então a morte enlanguesceu ao rever seu jardim e voou pela janela sob a forma de uma fria bruma branca." A morte tem seus sonhos, seu jardim, sua felicidade, sua nostalgia, sua esperança. As Elegias de Duíno também o dizem. É preciso saber cantar para a morte; e só aquele que sabe cantar para a vida sabe cantar para a morte. O imperador revive e quer recompensar o pássaro. Mas a compaixão não tem preço. O rouxinol recusa. Ele promete seu canto na solidão da noite, mas guarda sua liberdade - 
aquela que faz verter as lágrimas e convence até mesmo a morte. Gratuidade da doação, graça do doador: melhor que Orfeu, o rouxinol devolve a vida àquele que ele ama. A música para além de Orfeu. A arte ou a confiança.

Stravinsky, em sua transposição musical do conto ${ }^{4}$, leva muito a sério a oposição da inocência e do artifício, da improvisação do canto e da mecânica da execução, a tensão entre a tonalidade elegíaca e a tonalidade idílica. Ele dota o rouxinol da doçura das pastorais, valendo-se da melancolia que, desde o sannazarismo, assinala a atmosfera arcádia. O rouxinol é ingênuo, mas isto porque ele é um gênio, segundo Schiller: "Ingênuo, todo verdadeiro gênio deve sê-lo; ou ele não é um gênio. Apenas sua ingenuidade o converte em gênio" (Schiller, 1873, p. 351). As escolhas musicais de Stravinsky fazem ressoar esta ingenuidade lírica entre as duas vias "sentimentais" da elegia e do idílio.

A elegia, no sentido estrito, opõe a natureza à arte, o ideal à realidade; e faz da natureza e do ideal um objeto de luto, pois a primeira é perdida e o acesso ao segundo é apresentado como impossível. O idílio espécie de elegia no sentido amplo - faz dos dois um objeto de alegria, na medida em que são imaginados como reais (Schiller, 1873, p. 381).

O idílio se compraz em pintar a idade de ouro; ela é ameaçada pelo perigo de uma imobilidade inane. A elegia chora seu

\footnotetext{
${ }^{4}$ Trata-se, aqui, d'O Rouxinol, conto lírico (em três atos) composto por Stravinsky em 1914. O libreto foi escrito pelo próprio compositor russo (em colaboração com Stepan Nikolaevich Mitusov), a partir do já referido conto de Andersen. [N. do T.]
} 
próprio enlutamento sem fim. Como seria de prever, o rouxinol mecânico, como autômato suntuoso, é "barroquisante" e exótico. Rebuscado demais, dizia Andersen, herói da "maneira", criticado por Goethe na Simples imitação, maneira e estilo, assim como por Diderot, no final do Salão de 1767:

A maneira é um vício comum a todas as belas-artes. Suas origens são ainda mais secretas que a beleza. Ela possui não sei quê de original que seduz as crianças, que impressiona a multidão e que, às vezes, corrompe uma nação inteira. Mas ela é mais insuportável ao homem de gosto que a feiura, pois a feiura é natural [...] (Diderot, 1876, p. 369).

Música para ver tanto quanto para ouvir; música em que o ouvido se faz olho, para captar o brilho sarapintado de uma mise-en-scène pretensiosa. É ao pássaro mecânico, no entanto, que Stravinsky empresta sua própria música, como Wagner atribui aos personagens demoníacos de suas óperas a música mais revolucionária - a mais orientada em direção a Schoenberg.

Kant também possui um rouxinol, que surge na virada do $\S$ 42 da Crítica do Juízo:

Há coisa mais apreciada pelos poetas que o canto belo e encantador do rouxinol, em um bosquezinho solitário, numa calma noite de verão, sob a doce luz da lua? Todavia, há exemplos em que, não sendo possível encontrar nenhum cantor deste gênero, certo anfitrião malicioso enganou - aliás, para sua enorme satisfação 
- seus convidados vindos à sua casa para desfrutar do ar do campo, escondendo em um arbusto um jovem travesso capaz de imitar perfeitamente (com um caniço ou um junco na boca) este canto segundo a natureza. Mas a partir do momento em que se é convencido de que se trata de uma fraude, ninguém suporta ouvir por muito tempo este canto antes considerado tão atraente (Kant, 1965, p. 197).

A variante kantiana da fábula do rouxinol é considerada como uma peça no dossiê sobre o primado do belo natural ou do belo artístico. Ela é vista como uma defesa do natural contra os charmes do artifício. Kant submeteria a arte ao modelo da natureza e, em consequência disto, o artístico ao estético. De Hegel a Genette, os pensadores da arte retomaram o sentido do apólogo, distribuindo elogios e críticas da linha divisória entre artístico e estético, cujo mérito ou demérito remontam a Kant como a uma origem. Ao desvencilhar a autonomia de uma relação estética que não depende do êxito da obra de arte, Kant preserva o que mais lhe importa: uma beleza sem atrativo, livre do atrativo. Ele paga o preço deste resgate gratificando apenas a natureza com uma possibilidade de obter um "favor que é a única satisfação livre" (Kant, 1965, p. 72). A arte padeceria para chegar a isto sem resvalar no "como se"; logo, em uma imitação. O jogo se faz entre o gosto e o belo; e se o maior trunfo é a liberdade, trata-se de uma liberdade acantonada no exercício de um juízo. Arcádia na qual nenhum objeto de satisfação é arruinado pelo peso de sua existência; o favor se mostra quando a necessidade se cala. A filosofia kantiana afirma que a beleza não é uma coisa real, física ou metafísica. A beleza decorre apenas de uma 
função: aquela do juízo, que é uma atividade, uma atitude do espírito humano. Ela associa sua legitimidade a um desinteresse; mais exatamente, a um sem interesse. "O gosto é a faculdade de julgar um objeto ou um modo de representação, sem nenhum interesse, por uma satisfação ou uma insatisfação. Chamamos de belo o objeto de tal satisfação" (Kant, 1965, p. 73). Como vemos nesta definição, o belo se introduz em segundo lugar, como consequência, quando não o faz por efração. O sem interesse não concerne ao belo; ele é atribuído à Urteilskraft. O belo encontra-se na via passiva - produto do poder de julgar, qualificação que este atribui quando ele consegue suspender todo interesse. Somente o belo natural permite um julgamento estético puro e não um julgamento estético logicamente condicionado: "A fim de que possamos considerar o belo enquanto tal como um interesse imediato, é preciso que seja a natureza ou aquilo que tomamos por ela (o que a insinue a nós)." (Kant, 1965, p. 197-198).

A queda na história do rouxinol de Kant é a descoberta do embuste: "A partir do momento em que se é convencido de que se trata de uma fraude, ninguém suporta ouvir por muito tempo este canto antes considerado tão atraente." O que nos decepciona não é nenhuma qualidade do canto, mas a vontade maligna que nos induziu em erro. A exigência kantiana segundo a qual devemos renunciar a todo interesse na existência do objeto, a fim de que se efetue o juízo estético, supõe a separação entre o reino da beleza e o reino do atrativo. Ela obriga a um cálculo no qual investimos uma distância para nos desprendermos do Reiz da beleza. Exigir a indiferença conduz a uma postura realizada na tensão. Estamos próximos da impostura. Kant exige que realizemos o objetivo determinado por Diderot ao comediante, 
isto é, tender à insensibilidade, renunciar às emoções, aos afetos? A diferença é enorme: Diderot exige a insensibilidade para que a interpretação do comediante seja justa. Portanto, é como condição de possibilidade da justeza da obra, como método, que o insensível é exigido. Ora, o suspense kantiano só vale para o receptor e não concerne à obra de arte. Para alcançá-lo, o filósofo emprega um viés radical: a suspensão da existência do objeto do juízo de beleza.

Chamamos de interesse a satisfação que associamos à representação da existência de um objeto. [...] Todavia, quando se trata de saber se uma coisa é bela, não procuramos saber se nós mesmos, ou qualquer outra pessoa, temos ou mesmo poderíamos ter interesse na existência da coisa, mas como nós a julgamos ao considerá-la simplesmente (quer se trate de intuição, quer de reflexão). (Kant, 1965, p. 64-65)

Segue o exemplo do palácio:

Desejamos unicamente saber se a simples representação do objeto é em mim acompanhada por uma satisfação, tão indiferente quanto eu possa ser para a existência do objeto desta representação. Vê-se facilmente que o que importa para declarar belo o objeto e provar que tenho gosto é aquilo que descubro em mim em função desta representação; e não daquilo em que dependo da existência do objeto. Cada um deve reconhecer que um juízo sobre a beleza no qual se imiscui o menor interesse é muito parcial e não pode ser 
um juízo de gosto puro. Para desempenhar o papel de juiz em matéria de gosto não se deve preocupar de forma alguma com a existência do objeto, mas, pelo contrário, ser indiferente no tocante a isto (Id., Ibid., p. 65-66).

O belo e a arte interessam a Kant? Na história do rouxinol, nada é dito sobre o canto do pássaro. O que nos é narrado é um prazer honesto, socialmente interessante, em um plácido ambiente natural, ao que acreditamos ser um canto natural. O gosto (Crítica do Juizo, § 41) é Übergang: passagem do objeto ao sujeito e, assim, vetor de conhecimento e moralidade. O rouxinol não existe é um conto para crianças. A sorte que Kant reserva ao rouxinol é ser a mediação entre os sujeitos receptores: uma moeda da intersubjetividade. Em quê a parte estética pode ser salva nesta separação do artístico? O conto de Andersen e a música de Stravinsky nos dizem mais sobre isso do que Kant ou outra coisa; a obra de arte pensa para além do que a filosofia explica. Kant nos faz compreender que só a impossibilidade de um embuste assegura um estar junto, um Interesse que é também o que ele chama, no $\S 60$, de Teilnehmung, a participação, a partilha, evitando cuidadosamente o termo piedade, Mitleiden. A beleza do canto do rouxinol no conto ou na Ópera me garante que, se eu tiver confiança na beleza ou no amor (o canto de Orfeu), vencerei a morte e descobrirei o que é a relação com o outro. O Interesse, esta sociabilidade que Kant preconiza e que o senso comum apresenta, deve ser mais que uma evasiva da decepção. A confiança não é uma "não decepção": ela possui uma determinação positiva; ela engrandece nosso ser, o ser de cada sujeito. 
A nota do final do $\S 2$ da Crítica do Juízo determina que os juízos de gosto não produzem interesse para o sujeito. É preciso que haja uma sociedade para que a faculdade de julgar enquanto gosto obtenha um valor: aquele de uma civilidade que se se aprimora. Ora, nós somos interessados, independente de quanto o seja Kant. A confiança destrói o cálculo feito em nome do desinteresse nos prazeres e desprazeres, e transfigura a gestão ecônoma da descarga psíquica que sustenta o filósofo. Certamente a beleza não é um cânone, tampouco o nome do puro juízo de gosto: ela é doação. A indiferença procurada por Kant implica no recuo do sujeito. O prazer estético então surge defensivo: sua pureza não está ligada a uma fruição da forma, mas a um formalismo moral. A pusilanimidade que ele implica, esta desobrigação que ele opera, assemelha-se a um medo da dor, a ponto de confundir-se com ela. Por que a forma recusa a dor, a dor "santificada" da qual fala Nietzsche no Crepúsculo dos ídolos? Será toda forma, toda a forma? A dor só está do lado da empatia? Na introdução escrita por Aby Warburg ao seu Bilderatlas, a primeira frase diz:

A criação constante da distância entre o sujeito e o mundo exterior é o que podemos designar como o ato fundamental da civilização. Se o espaço intermediário entre o sujeito e o mundo exterior torna-se o substrato da criação artística, temos as premissas pelas quais a consciência desta distância pode tornar-se uma função social durável que, mediante a alternância rítmica da identificação com o objeto e o retorno à sophrosunè, apresenta o círculo da cosmologia das imagens e dos signos (Warburg, 2012, p. 54). 
A experiência se constitui no espaço intermediário; ela possui um caráter rítmico: o ritmo da relação, do movimento entre os polos. Ao dizer "entre identificação com o objeto e retorno à sophrosunè", Warburg estaria indicando que "entre forma e empatia" significaria entre duas relações para consigo? O Schein apolíneo, que é também uma categoria da embriaguez, uma embriaguez que, segundo o Crepúsculo dos ídolos, "antes de tudo, produz a irritação do olho, que dá ao olho a faculdade da visão", não é um engodo: ele exprime a confiança que se deve ter. Ao falar de Goethe, o mesmo Nietzsche afirma ainda: "Tal espírito liberado aparece no centro do universo em um fatalismo alegre e confiante, com a fé em que só é condenável o que existe isoladamente, e em que tudo se resolve e se afirma no todo. Ele não nega mais..." (Nietzsche, 1970, p. 123). Sobre o modo mítico contos e lendas da beleza -, o rouxinol interessa à nossa própria superação. Parte arcaica, ele guarda sua história antiga. Seu canto renova o laço das Musas com sua mãe Mnemósine e evoca a presença de Dionísio - o aulos que é a sua ideia musical, e isso até Stravinsky -, no seio mesmo da serenidade do apolíneo. Pássaro noturno, ele canta nos bosques - voz oculta que faz verter as lágrimas; mas lágrimas benfazejas, pois as lágrimas que ele provoca dissolvem a dureza dos corações. As lágrimas da dor misturam-se às lágrimas daquilo que é uma redenção, uma reconciliação. A salvação concedida pela graça afugenta os espectros que assombram nossas noites. Música desejada por uma razão inquieta com ela mesma, o rouxinol é a voz harmoniosa do coração em uma nostalgia que lhe concede sua força utópica. A melodia do rouxinol vivo é uma arte na qual podemos estabelecer nossa confiança: sua justeza não se perde; ele não mente. Longe de ser preciso se desprender da emoção que seu canto 
suscita, deve-se ver nele uma pedra de toque da consistência de sua música, aquela que afugenta os espectros que carregamos conosco e dos quais esperamos estar libertos. Pois é preciso que haja pressão, necessidade ou dever; dimensão ética e estética; ter a experiência do sofrimento, da indiferença dos outros, do medo da morte. É isto o que diz o conto, pelo menos: a justeza deslumbrante do canto do rouxinol só se manifesta totalmente quando o canto combate a morte na cabeceira do velho imperador.

\section{Laocoonte e a piedade}

O rouxinol kantiano não salva ninguém: seu canto deveria ser o "símbolo do bem moral"; o embuste revelado decepciona, estraga o sarau. A vontade de artifício do anfitrião tornou impossível a instauração de uma pequena comunidade seleta, para ficarmos num bom rousseauísmo. Se a sua fábula exemplifica as relações entre o belo e o bem moral, seu rouxinol nada tem de exemplar. É verdade que o $\S 42$ não pertence às páginas que Kant consagra às artes em sua Crítica. Que sorte reserva o filósofo a isto que equivaleria a uma fábula estética do século XVIII - o Laocoonte, ou mais exatamente o debate sobre o grupo esculpido? O $\S 48$ faz alusão a ele, pelo menos quando se leu Lessing, como era o caso de Kant:

As belas-artes mostram sua superioridade precisamente pelo fato de que elas produzem uma bela descrição de coisas que, na natureza, seriam feias ou desagradáveis. Enquanto coisas nocivas, as fúrias, as doenças, as devastações da guerra podem ser descritas de maneira 
belíssima e podem mesmo ser representadas por pinturas. Uma só forma de feiura não pode ser representada de maneira natural sem aniquilar toda satisfação e, por conseguinte, toda beleza artística: é aquela que excita a repugnância (Kant, 1965, p. 210).

O que diz Lessing em seu Laocoonte, sobre os limites da pintura e da poesia (1756)?

O exemplo de Timantes não mostra como se deve conduzir a expressão para além dos limites da arte, mas como se deve submetê-la à primeira lei da arte: a lei da beleza. Se neste momento aplicarmos esta lei ao Laocoonte, veremos representada a maior beleza compatível com a dor física: esta, em toda a sua violência deformadora, não poderia se aliar com aquela. O artista, então, era obrigado a reduzi-la, a moderar este grito [transformando-o] em gemido; não porque o grito indica uma alma baixa, mas porque ele dá ao rosto um aspecto repulsivo. Imaginai Laocoonte com a boca escancarada e julgai. Fazei-o gritar e vereis. Era uma imagem que inspirava compaixão, pois encarnava simultaneamente a beleza e a dor; agora é uma imagem hedionda, monstruosa, da qual gostaríamos de desviar nosso olhar; pois a visão da dor excita a repugnância sem que a beleza do objeto sofredor possa transformar esta repugnância em um doce sentimento de compaixão (Lessing, 1802, p. 18-19). 
A repugnância é um obstáculo - obstáculo à fruição estética, para Kant; obstáculo ao êxito artístico, para Lessing.

Em primeiro lugar, sigamos Kant. A excitação da repugnância põe a alma em tensão. Abalada, a imaginação sofre uma invasão. O objeto repugnante se impõe à fruição e nós resistimos a ele com força, violência (Gewalt). Mais nenhuma liberdade é possível em um exercício harmonioso de nossas faculdades. Pressão, resistência - como este prazer desinteressado poderia se instalar, quando a alma se torna um campo de forças contraditórias dominado pela existência insistente do objeto? A repugnância é uma experiência-limite, pois o objeto e o sujeito encontramse baralhados; nenhuma representação do objeto é possível. A repugnância faz com que aquele que a experimenta perca tudo o que a teoria do conhecimento da Crítica da Razão Pura lhe atribuía como funcionamento do entendimento, esta aplicação regrada das categorias aos fenômenos. Ela [a repugnância] torna impossível a livre atuação das faculdades, tal como a descreve a Crítica do Juízo: nenhuma distância e nenhuma gratuidade do favor. A repugnância perturba a alma e o espírito. A desorientação que ela produz concerne à relação com a representação do mundo que podemos ter. A repugnância arruína a mise-enscène do desinteresse e incita a exclusão do atrativo da esfera do belo, em razão do caráter intrusivo do objeto e da reação corporal que ele impõe. É por isso que Kant exclui a repugnância. Lessing diz algo totalmente diverso. Assim como Kant, certamente ele vê na repugnância um impedimento à beleza; mas, a seu ver, a beleza está no objeto, e não em um sujeito capaz de privar-se de seus interesses para proferir um juízo de beleza. E a beleza, única preocupação de Lessing em matéria de pintura ou de escultura, só pode ser uma muralha sob condição de in- 
tegrar o plinto que é a repugnância no edifício da beleza. Mas esta integração implica uma força, uma eficácia da piedade. Se o feio também é natural, o repugnante é inumano: sua violência é deformadora, torna impossível a definição de uma forma e faz com que, em sua relação consigo mesmo, o homem corra o risco de ser oprimido pelo inumano. A beleza deve capturar as forças selvagens das quais ela provém. A arte inventa a beleza onde a natureza a abandonou: nas margens bárbaras onde a quietude não alcança; onde a repugnância e suas forças de excitação rebentam. As Luzes não se encontram em uma denegação da violência, do mal, do atrativo do mal. Elas confiam na força da beleza artística que permite ao sujeito absorver-se em um objeto extraordinário. Pelo objeto, elimina-se uma relação de si para consigo na qual o sujeito seria submerso pelo informe ameaçador que é o repugnante. Ora, para que esta operação se realize, segundo Lessing, deve-se admitir que a dor exista e confiar à piedade - uma piedade concebida como método da arte - a tarefa de nos desviar da repugnância e de assegurar, assim, o poder que a beleza possui de guiar-nos em direção ao objeto. Sem a piedade provocada pela decisão plástica do artista, nós nos desviaríamos do Laocoonte, tomados pela repugnância que a desfiguração provoca em nós. Portanto, é em torno da piedade que se produz a distância entre Lessing e Kant, pois ela é o obstáculo da realidade da obra de arte, inclusive ou exemplarmente na sua dimensão trágica. Se o artista deve visar a beleza, isto não se deve ao fato de ela ser um cânone: é para assegurar que a piedade jamais seja submersa pela repugnância. O que impressiona na análise de Lessing é a designação do ponto de não retorno que é a repugnância e, ao mesmo tempo, o papel da piedade como garantia de nosso acesso à beleza. 
A tese do prazer desinteressado faz com que falte a Kant a beleza artística. Ora, a despeito de Kant, a função do belo não é apenas apaziguar, curar, ligar novamente a separação que se instalou em nosso psiquismo, mas repelir o terror do repugnante, nosso interesse pela repugnância; e oferecer-nos um prazer positivo. A concepção kantiana do prazer estético é "privativa". O interesse indica um investimento e a possibilidade, para além dos conflitos que ele pode engendrar, de uma passagem à realidade, sob a perspectiva de uma satisfação em um ser ou um objeto existente. Se a piedade não é mencionada por Kant, é porque ela perturba a edificação do "sem interesse" e, ao mesmo tempo, põe em questão a "pura forma". Sem interesse e pura forma são o reverso e o anverso de uma mesma moeda: aquela de uma estética que não admite nenhum objeto como sujeito - face a ele. $\mathrm{O}$ que implica enfim na desvalorização, por tal estética, não só do objeto, mas também do sujeito que se encontra reduzido a uma experiência imaginária, descorporificada: o proferimento de um juízo de beleza que, sem dúvida, postula o acordo dos outros sujeitos, mas com os quais ele não divide o peso do sofrimento sentido perante a dor nem o movimento da piedade. O oblívio de Kant surpreende na medida em que poderíamos sustentar que a piedade reforçaria o sensus communis. É a este título, aliás, que as Luzes se aplicam a reconhecer na piedade uma alavanca decisiva: a piedade nos restitui a nós mesmos ao abrir-nos a via do outro. Ela é interesse para os seres vivos que nos cercam; e muito particularmente para o ser humano. Lessing enxerga aí "o valor supremo do homem esclarecido, concebido como ser moral e social" (Carta de 13 de novembro de 1756 a Nicolai). Sensível, a piedade torna sensível; e assim socializa e civiliza. Por que Kant recusa a piedade, afastando-se assim dos artistas 
e dos pensadores de seu século, do pensamento das artes que se constrói; e de um Rousseau, que ele não deixava de ler e reler?

O discurso moral - quando não é moralizador - que floresce nas Luzes a propósito das artes encoraja o desenvolvimento dos gêneros intermediários: romances, dramas, confissões epistolares; quadros impressos daquilo que Michael Fried chama de teatralidade. ${ }^{5}$ Trata-se de comover a alma para educá-la mais depressa, ao persuadi-la com eficácia mediante uma retórica das lágrimas ou, pelo menos, da lacrimação. Compreende-se, sob este aspecto, as precauções teóricas das quais Kant se utiliza, por um lado, e sua preferência pelo sem interesse em face de uma rebentação do interessante, que é também a escolha de uma coerência sistemática do filósofo. Um sujeito transcendental, como o sujeito kantiano, implica a eliminação de uma subjetividade invadida narcisicamente por um "tormento de si" (a expressão é de Goethe, a propósito da geração Werther). Um sujeito transcendental não possui lágrimas; e, aliás, não saberia se comprazer em choramingar. Mas este sujeito transcendental vive em sociedade; e é preciso que seu gosto seja exercido, contribua para aprimorar uma civilidade. Por esta mesma razão, os juízos de gosto são "interessantes", por mais desinteressados que possam ser. Trata-se de uma resolução, no crepúsculo das Luzes, da oposição entre o Discurso sobre as ciências e as artes e as diversas apologias do luxo que tentariam combinar o desenvolvimento de um gosto melhor do sujeito pelo jogo das comparações e um verdadeiro progresso social? Voltaire e Rousseau reconciliados para assentar o motivo da "insociável sociabilidade" e assim congraçar o século e as reflexões sobre o gosto que Kant havia abandonado em proveito da construção de uma Crítica da

\footnotetext{
${ }^{5}$ Cf. Fried, 1990.
} 
faculdade de julgar. Aos olhos de Kant, o gosto é uma pedagogia da liberdade: ele contribui com a criação e a manifestação da cultura. O assentimento que funda, no segundo momento da analítica do belo, o valor comum do belo (Gemeingültigkeit, Einstimmung), não é jamais pressionado. Uma liberdade se adquire nos jogos do belo e se exerce pouco a pouco, até assumir esse caráter agudo, akut, que qualifica todo bom juízo. Esta liberdade (Gunst, o favor do § 5) é oferecida a todo sujeito, por maior ou menor que seja sua sujeição política ou ética, psíquica ou fisiológica. A humanidade tem direito a esta Arcádia. Mas é uma Arcádia - asseptizada - que não dá nenhum lugar às artes nem às obras. Que a única consistência da obra chegue a ela [Arcádia] de um belo entendido como símbolo do bem moral não lhe assegura nenhuma justeza.

Em uma estética kantiana, se as obras podem exemplificar a moralidade, elas só alcançam uma exemplaridade com muita dificuldade; mas não há nada grave nem triste nesta impotência à qual Kant as condena. A beleza do canto do rouxinol vivo, sua força redentora; a dor de Laocoonte; o terror da morte que aflige o velho imperador da China, assim como o sacerdote troiano, poderiam nos interessar muito intensamente, nos emocionar muito além daquilo que uma faculdade de juízo pode sustentar como violência do afeto, potência do atrativo, força das necessidades e sonho de encontrar em um objeto - uma obra de arte - a voz harmoniosa que consola, reconcilia e une. A Kant basta que as obras - de preferência aquelas do gênio - possam contribuir com "a cultura das faculdades da alma". Pois "a sociabilidade, ao convir à espécie", está ligada ao "sentimento universal de sympathia", este Teilnehmungsgefühl que, com a "comunicação", o "comunicar-se de uma maneira íntima e universal", fazem-nos 
entrar na cultura. É preciso esquecer a música do canto do rouxinol, como o homem em sofrimento antigo que é o Laocoonte.

\section{Referências bibliográficas}

BEnJAmin, W. Oeuvres. t. I. Trad. fr. M. de Gandillac, R. Rochlitz et p. Rusch. Paris: Gallimard, 2000.

CASSIRER, E. Idee und Gestalt. Darmstadt: Wissenschaftliche Buchgesellschaft, 1975.

DIDEROT, D.; D'ALEMBERT, J. Encyclopédie, ou dictionnaire raisonné des sciences, des arts et des métiers. 17 vols. Paris, 1751 - 1765. [Edição eletrônica pela Universidade de Chicago, a cargo de Robert Morrissey e Glenn Roe. Disponível em: http://encyclopedie.uchicago.edu/node/176.]

DIDEROT, Denis. Oeuvres complètes. t. XI. Ed. établie par J. Assézat et M. Tourneux. Paris: Garnier Frères, 1876.

FRIED, M. La Place du spectateur. Esthétique et origines de la peinture moderne (1980). Trad. fr. Claire Brunet. Paris: Gallimard, 1990.

GIL, Fernando. Exemple et pierre de touche chez Kant, Analise, $\mathrm{n}^{\circ} 15$, Lisboa, 1991.

- La bonne description, Enquête, $\mathrm{n}^{\circ}$ 6, 1998.

GOETHE, J. W.; SCHILLER, F. Correspondance (1794-1805). t. I. Trad. fr. L. Herr. Paris: Gallimard, 1994.

KANT, E. Critique de la faculté de juger. Trad. fr. A. Philonenko. Paris: Vrin, 1965.

- Métaphysique des mœurs - deuxième partie - Doctrine de la vertu. Trad. fr. Philonenko. Paris: Vrin, 1985a.

- Critique de la raison pratique. In: Euvres philosophiques.

t. II. Trad. Fr. Ferdinand Alquié et alii. Paris: Gallimard, 
1985b.

- Critique de la raison pure. Trad. fr. A Tremesaygnes et B. Pacaud. Paris: PUF, 1986.

LESSING, G. E. Laocoon (1766). Trad. Fr. Ch. Vanderbourg. Paris: Renouard, 1802.

_- . Traités sur la fable. Trad. fr. N. Rialland. Paris: Vrin, 2008.

NIETZSCHE, F. Le Crépuscule des idoles (1888). Trad. Fr. H. Albert. Paris: Denoël / Gonthier, 1970.

ROUSSEAU, J.-J. Oeuvres complètes. t. IV. Éd. B. Gagnebin et M. Raymond. Paris: Gallimard, 1969.

SCHILLER, F. De la poésie naïve et sentimentale. In: Oeuvres de Schiller. Trad. Fr. Ad.Régnier. t. VIII. Paris: Librairie Hachette, 1873.

WARBURG, A. L'Atlas Mnémosyne (1921-1929). Ed. R. Recht. Trad. fr. S. Zilberfarb. Paris: l'Écarquillé/INHA, 2012. 
